\title{
Diversity of culturable marine bacteria on the coastline of the central area of San Jorge Gulf, Argentina
}

\author{
Diversidad de las bacterias cultivables de la costa del centro del golfo San Jorge, Argentina
}

\author{
Graciela N. Pucci' ${ }^{1}$, Adrián J. Acuña ${ }^{1}$, Natalia L. Tonin ${ }^{1}$, \\ María C. Tiedemann ${ }^{1}$ and Oscar H. Pucci ${ }^{1}$
}

\begin{abstract}
${ }^{1}$ Centro de Estudios e Investigación en Microbiología Aplicada (CEIMA), Facultad de Ciencias Naturales, Universidad Nacional de la Patagonia San Juan Bosco, Ruta Provincial No¹ 4 km. Comodoro Rivadavia (CP 9000), Chubut, Argentina. granapu@unpata.edu.ar
\end{abstract}

\begin{abstract}
This study aims to isolate and identify culturable marine bacteria from 4 locations in the San Jorge Gulf. A total of 1,532 strains were isolated using oligotrophic, heterotrophic and hydrocarbondegrading bacteria media, and identified with reference to bacterial fatty acid methyl ester (FAME) profiles. Gram-negative bacteria were the most abundant, Pseudoalteromonas comprised $17 \%$ of the isolated bacteria, followed by Pseudomonas, with $11.14 \%$. The Gram-positive bacteria genera identified were Staphylococcus, Bacillus and Micrococcus. In addition, those bacteria able to degrade hydrocarbons were: Arthrobacter, Dietzia, Acinetobacter, Microbacterium, Micrococcus, Bacillus, Pseudomonas and Pseudoalteromonas.
\end{abstract}

Key words: Marine bacterial diversity, fatty acids, sediments, San Jorge Gulf

\section{INTRODUCTION}

The composition of bacterial communities in estuaries and coastal regions of oceans is largely unknown, despite the substantial roles of many coastal, bacteria play in critical biogeochemical cycles and the potential utility for bioremediation and other biotechnological applications. The lack of knowledge of this important group of microorganisms can be attributed directly to their cultivability by standard microbiological techniques and to the reluctance on the part of marine microbiologists to study the small, potentially unrepresentative group of bacterioplankton that can be readily cultured from coastal seawater (Gonzales et al. 1997). Many bacterial strains have been isolated from coastal and oceanic environments; these bacteria, including the genera Pseudomonas, Vibrio, and Flavobacterium, have been considered to be representative of marine bacteria (Harayama et al. 2004). In fact, diverse petroleum degrading bacteria inhabit marine environments such as Alcanivorax (Head et al. 2006), Cycloclasticus (Kasai et al. 2002), Marinobacter (Gerdes et al. 2005), Neptunomonas (Hedlund et al. 1999) and 'nonprofessional' hydrocarbonoclastic bacteria such as Vibrio, Pseudoalteromonas and Halomonas.

The aim of this study was to determine the biodiversity of culturable bacteria in the San Jorge Gulf, where there is a long history of small spills generated by chronic pollution (oil terminals, ships and inadequate sewage systems). In order to reach our objective, the bacteria were isolated using oligotrophic, heterotrophic and hydrocarbon degrading media and the bacteria were identified with reference to bacterial fatty acid methyl ester (FAME) profiles.

\section{MATERIALS AND METHODS}

Over the course of one year, in 2006, a total of 1,532 bacteria strains were isolated.These strains were obtained from samples taken in 4 different points of the San Jorge Gulf: Caleta Córdova (CC S45 44.384 WO67 $^{\circ} 22.633$ ); Comodoro Rivadavia (CR S45 52.954 WO67 30.205 ); Rada Tilly (RT S45 56.720 WO67 33.154 ) and Caleta Olivia (CO S46 ${ }^{\circ} 27.583 \mathrm{WO}^{\circ} 29.653$ ). The 3 media used for culture were: BBR agar for oligotrophic bacteria $\left(\mathrm{g} \mathrm{L}^{-1}\right.$ : Tripteine 0.5 , yeast extract $0.5, \mathrm{~K}_{2} \mathrm{HPO}_{4} 1 ;(\mathrm{NH} 4)_{2} \mathrm{SO}_{4} 2$; agar-agar 15 , sterile marine water $700 \mathrm{~mL}$, sterile water 300 $\mathrm{mL}, \mathrm{pH}$ 7.2); MBM-PG agar for hydrocarbon-degrading bacteria (g L-1 $\mathrm{NaCl} 5$ g, $\mathrm{K}_{2} \mathrm{PO}_{4} \mathrm{H} 0.5$ g, $\mathrm{NH}_{4} \mathrm{PO}_{4} \mathrm{H}_{2} 0.5$ g, $\left(\mathrm{NH}_{4}\right)_{2} \mathrm{SO}_{4} 1 \mathrm{~g}, \mathrm{Mg} \mathrm{SO}_{4} 0.2 \mathrm{~g}, \mathrm{KNO}_{3} 3 \mathrm{~g}, \mathrm{FeSO}_{4} 0.05 \mathrm{~g}$, distilled water $1000 \mathrm{~mL}$ ) which was distributed in a Petri plate and after solidification, $30 \mu \mathrm{L}$ of a mixture 1:1 of petroleum-diesel oil were spread on the surface (Pucci \& Pucci 2003); and BRN agar for heterotrophic bacteria (g L-1: Tripteine 5 , yeast extract $1, \mathrm{~K}_{2} \mathrm{HPO}_{4} 1 ;\left(\mathrm{NH}_{4}\right)_{2} \mathrm{SO}_{4} 2$; 
agar-agar 15, sterile marine water $700 \mathrm{~mL}$, sterile water 300 $\mathrm{mL}, \mathrm{pH}$ 7.2). The isolates were identified based on wholecell cellular fatty acids, derivatized to methyl esters, i.e., FAMEs and analyzed by gas chromatography (GC) using the MIDI system (MIDI, Newark, DE). The analysis was performed using the Sherlock Microbial Identification system TSBA 6.0 software and the library general system software version 6.0.

\section{RESULT AND DISCUSSION}

The present study employed Culture-dependent methods to assess the diversity of bacteria in marine sediment and seawater collected from the San Jorge Gulf. A total of 1,532 strains were isolated but only 745 were identified by MIDI. On the basis of MIDI, these 745 strains were classified as 65 genera and 150 species. There were 45 genera with less than 10 strains each. Gram-negative bacteria were abundant; Pseudoalteromonas represented $17 \%$ of total number of bacteria, followed by Pseudomonas with $11.14 \%$. On the other hand, the Gram- positive bacteria were Bacillus (6.98\%); Staphylococcus (5.1\%) and Micrococcus (4.7\%). The other strains are shown in Table 1.

Gram-negative strains represented 75\% from the total strains, predominating over the total number of bacteria identified (Table 2). The major percentage of Gram-positive bacteria was found during the winter, in the four different points sampled, being Rada Tilly the city with the highest percentage of bacteria (40.91\% of Gram-positive bacteria and $59.09 \%$ Gram-negative bacteria). The Shannon diversity index were calculated, showed high values during autumn, in the city of Comodoro Rivadavia, when BRN culture medium was used (Table 2).

The number of strains found was quite equal on the BBR and BRN media; both without oil; but the number of strains isolated were lower in hydrocarbon culture media. The oil degrading bacteria were slow growing bacteria and colonies were visible after seven days; however, on the BBR and BRN media, the bacteria were visible after 24-48 h. Pseudomonas genus was more abundant on the

Table 1. Percentage composition of bacterial species from San Jorge Gulf, identified by isolates cultured in BBR, BRN and hydrocarbon degrading media / Composición porcentual de la identificación de las especies bacterianas del Golfo San Jorge, las cuales fueron asiladas de los medios de cultivo BBR, BRN y medio de cultivo con hidrocarburo

\begin{tabular}{|c|c|c|c|}
\hline Identification & $\%$ & Identification & $\%$ \\
\hline Pseudoalteromonas spp. & 17.05 & Salmonella & 1.88 \\
\hline Pseudomonas spp. & 11.14 & Microbacterium & 1.48 \\
\hline Bacillus spp. & 6.98 & Zobellia uliginosa, Sphingopyxis spp., Escherichia spp. & 1.34 \\
\hline Staphylococcus spp. & 5.10 & Brevibacillus spp., Arthrobacter spp. & 1.21 \\
\hline Micrococcus spp. & 4.70 & Rhodovolum sulfidophilum, Neisseria spp. & 0.94 \\
\hline Rhodobacter spp. & 4.16 & Paenibacillus spp., Flavimonas spp. & 0.81 \\
\hline Acinetobacter spp. & 3.89 & Dietzia maris, Bradyrhizobium japonicum & 0.67 \\
\hline Vibrio spp. & 3.89 & A & 0.54 \\
\hline Psychrobacter immobilis & 3.76 & & \\
\hline Aeromonas spp. & 3.76 & B & 0.40 \\
\hline Kocuria spp. & 2.95 & & \\
\hline $\begin{array}{l}\text { Photobacterium, } \\
\text { Ocrhobactrum anthropi }\end{array}$ & 2.68 & $\mathrm{C}$ & 0.27 \\
\hline $\begin{array}{l}\text { Shewanella putrefaciens algae, } \\
\text { Brevundimonas spp. }\end{array}$ & 2.01 & $\mathrm{D}$ & 0.13 \\
\hline
\end{tabular}

A: Rhodococcus spp., Gluconobacter asa/oxydans, Curtobacteriums spp., B: Roseomonas spp., Pseudoxantomonas spp., Paracoccus denitrificans, Nocardia subflava, C: Xanthobacter spp., Virgibacillus pantothenticus, Stenotrophomonas maltophilia, D: Yersinia frederiksenii, Sporosarcina globispora, Rothia dentocariosa, Proteus vulgaris, Photorhabdus luminescens luminescens, Pectobacterium carotovorum, Paucimonas lemoignei, Nocardia albus, Nesterenkonia halobia, Lysobacter enzymogenes enzymogenes, Lecheonella flava, Kurthia gibsonii, Flavobacterium ferrogineum, Enterococcus feacalis, Clavibacter michganensis insidiosum, Cellulomonas spp., Burkholderia spp. 
BRN medium than on the hydrocarbon degrading bacteria medium, despite the fact that this genus is known by its metabolism in the use of hydrocarbon (Atlas 1981, Gerdes et al. 2005). In fact, Ps. putida and Ps. stutzeri were found in concordance with Röling et al. (2004). This genus has a rapid growth rate when conditions favour it, being widely known for its ability to use hydrocarbons as carbon source (Atlas 1981). The Alcanivorax borkumensis and Pseudomonas stutzeri strains dominated the initial stage of degradation of hydrocarbon. Another strain was the Acinetobacter, who is characterized by producing biosurfactants, which increased the bioavailability of water-insoluble products (Toren et al. 2001, Ron \& Rosemberg 2002).

The major percentage of bacteria identified was $17 \%$ corresponding to Pseudoalteromonas, which were found in marine environments and have the ability to use hydrocarbons; this genus can be associated to Alteromonas and Shewanella, all marine heterotrophic Gammaprotobacterias (Ivanova et al. 2004). Other hydrocarbon degrading bacteria found were Rhodococcus, which have a greater capacity to survive in adverse conditions, are able to use different hydrocarbon and have catabolic versatility (Whyte et al. 1999, Ruberto et al. 2005). Besides, Rhodococcus is the most common genus of Nocardiacea recovered from marine sediment (Gontang et al. 2007). Hydrocarbon degrading bacteria diversity on the San Jorge Gulf Coast has shown a genus that would be able to use hydrocarbons against possible oil spills on the coasts of the cities studied.

Nutrient concentrations in seawater and intertidal sediments were low and this affected the growth of enteric bacteria. However, we found and identified some Escherichia, Salmonellas and Proteus. In fact, the conditions of salinity, temperature and light can limit the survival of these species (Rozen \& Shimshon 2001). However, some of them, e.g., E. coli, can survive up to 13 days in water and marine sediment (Le Guyarder et al. 1991). E. coli was present in the city of Comodoro Rivadavia, which is subjected to a wide spatial fluctuation of faecal contamination, caused by the pouring of untreated sewage water into the sea; enteropathogenic bacteria were not found in any other sampling point.

MIDI system identified Shewanella algae (2\%), which is an opportunistic pathogen (Holt et al. 1997, 2005). Bacteria of the genus Shewanella have been studied in the past decade because of their important role in cometabolic bioremediation of halogenated compounds, petroleum products and because of their ability to reduce the magnesium and iron oxide. However, one of their main features is the ability to produce polyunsaturated fatty acids (Russell \& Nichols 1999).

Table 2. Percentage of Gram (\%) and Shannon diversity index ( $\left.\mathrm{H}^{\prime}\right)$ for season, media, and sites in San Jorge Gulf / Porcentajes de gram e índice de Shannon para las estaciones, medio de cultivo utilizado y ciudades estudiadas en el Golfo San Jorge

\begin{tabular}{lccc}
\hline & $\begin{array}{c}\text { \% Gram positive } \\
\text { bacteria }\end{array}$ & $\begin{array}{c}\text { \% Gram negative } \\
\text { bacteria }\end{array}$ & $\begin{array}{c}\text { Shannon diversity } \\
\text { index }\left(\mathrm{H}^{\prime}\right)\end{array}$ \\
\hline Season & & & \\
Spring & 17.16 & 82.09 & 3.165 \\
Summer & 21.63 & 79.18 & 3.707 \\
Autumn & 27.40 & 72.60 & 3.935 \\
Winter & 34.42 & 66.23 & 3.835 \\
Media & & & 3.884 \\
BBR & 19.61 & 80.78 & 4.133 \\
BRN & 25.38 & 75.38 & 3.729 \\
PGO & 29.68 & 70.32 & \\
Sites & & & 3.73 \\
Rada Tilly & 40.91 & 59.09 & 3.158 \\
Caleta Córdova & 26.61 & 73.39 & 3.255 \\
Caleta Olivia & 22.33 & 79.13 & 3.886 \\
Comodoro Rivadavia & 15.06 & 84.94 & \\
\hline
\end{tabular}


Sampling site pollution determined the frequency of strains. In the correspondence analysis, Comodoro Rivadavia was associated with Enterobacterias due to the fact that these strains are poured into the sea by an inefficient sewage system. This type of microorganisms has the ability to withstand for long periods in sediments (Viera et al. 2001), their abundance demonstrates the degree of contamination of feacal origin that these beaches in the city contain. The latter is of great importance due to the risk of transmitting infectious diseases via feacal oral route. Comodoro Rivadavia sediment samples are related by strains that are able to use hydrocarbons; this is because in both sampling sites, there are potential sources of pollution by oil, a fuel discharge and untreated effluent discharges from the industrial area in the city of Comodoro Rivadavia. This shows the adaptive ability of microorganisms to exploit small-scale oil spills.
Comodoro Rivadavia and Rada Tilly are related to certain groups of bacteria e.g. Pseudoalteromonas, Pseudomonas, Micrococcus and Photobacterium (Fig. 1 ), possibly because the area between these two cities is greatly contaminated by the municipal garbage landfill, located in front to the beach area. Besides, this pollution is also increased by the effluents poured to the sea by an inefficient sewage system, which introduces a great number of bacteria into the ecological system, resulting in the highest diversity index, especially in Comodoro Rivadavia.

The present investigation contributes to the knowledge of culturable heterotrophic, oligotrophic and hydrocarbonoclastic bacteria in the sediment and seawater of San Jorge Gulf, where 65 genera and 150 species were found, most of which were hydrocarbon degrading bacteria, capable of using the hydrocarbon on small scale spills. There were many bacteria that MIDI could not identify.

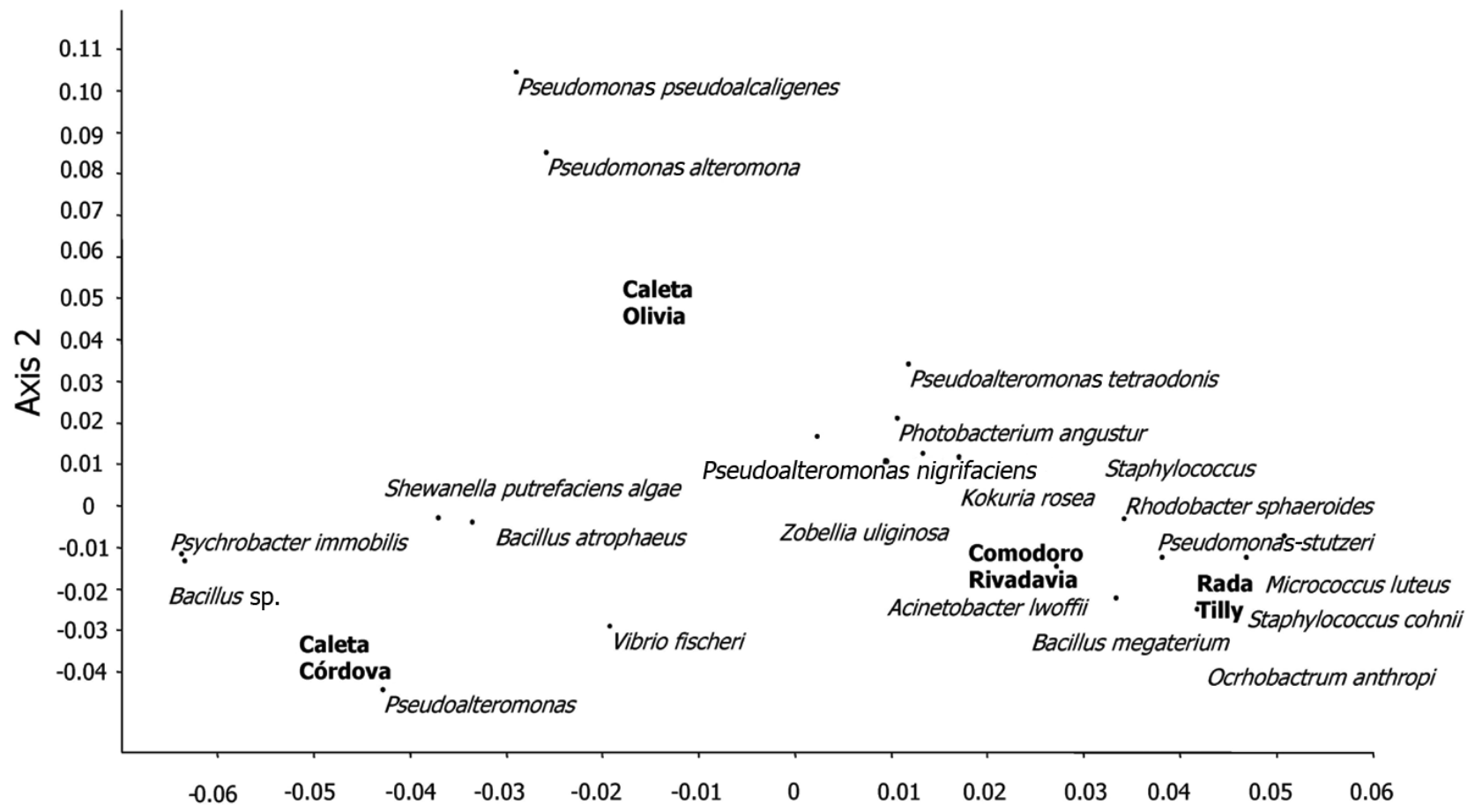

Axis 1

Figure 1. Correspondence analysis biplot between bacterial identities (acording to fatty acids methyl ester (FAMEs) profiles) and four coastal cities of Argentina (in bold) / Análisis de correspondencia entre entidades bacterianas (identificadas por los ácidos grasos de sus membranas) y cuatro ciudades costeras de Argentina (en negrita) 


\section{ACKNowledgments}

We acknowledge the financial support of CEIMA and UNPSJB. We sincerely thank Mirta Leiva and Miriam Robledo for their invaluable support and advice on technical aspects of this work.

\section{LITERATURE CITED}

Atlas RM. 1981. Microbial degradation of petroleum hydrocarbons: an environmental perspective. Microbiological Reviews 45: 180-209.

Gerdes B, R Brinkmeyer, G Dieckmann \& E Helmke. 2005. Influence of crude oil on changes of bacterial communities in Arctic sea-ice. FEMS Microbiology Ecology 53: 129139.

Gontang EA, W Fenical \& PR Jensen. 2007. Phylogenetic diversity of Gram-Positive bacteria cultured from marine sediments. Applied and Environmental Microbiology 73: 3272-3282.

Gonzales J \& MA Moran. 1997. Numerical dominance of a group of marine bacteria in the alpha-subclass of the class Proteobacteria in coastal seawater. Applied and Environmental Microbiology 63: 4237-4242.

Harayama S, Y Kasai \& A Hara. 2004. Microbial communities in oil-contaminated seawater. Current Opinion in Biotechnology 15: 205-214.

Head IM, DM Jones \& WFM Röling. 2006. Marine microorganisms make a meal of oil. Nature 4: 173-182.

Hedlund BP, AD Geiselbrecht, TJ Bair \& JT Staley. 1999. Polycyclic aromatic hydrocarbon degradation by a new marine bacterium, Neptunomonas naphthovorans gen. nov., sp. nov. Applied and Environmental Microbiology 65: 251259 .

Holt HM, P Sógaard \& B Gahrn-Hansen. 1997. Ear infection with Shewanella alga. A bacteriologic, clinical and epidiemological study of 97 cases. Clinical Microbiology and Infection 3: 329-334.

Holt HM, B Gahrn-Hansen \& B Bruun. 2005. Shewanella algae and Shewanella putrefaciens: clinical and microbiological characteristics. Clinical Microbiology and Infection 11: 347-352.

Ivanova E, S Flavier \& R Christen. 2004. Phylogenetic relationships among marine Alteromonas-like proteobacteria: emended escription of the family Alteromonadaceae and proposal of Pseudoalteromonadaceae fam. nov., Colwelliaceae fam. nov., Shewanellaceae fam. nov., Moritellaceae fam. nov., Ferrimonadaceae fam. nov., Idiomarinaceae fam. nov. and Psychromonadaceae fam. Nov. International Journal of Systematic and Evolutionary Microbiology 54: 1773-1788.
Kasai Y, H Kishira \& S Harayama. 2002. Bacteria belonging to the genus Cycloclasticus play a primary role in the degradation of aromatic hydrocarbons released in a marine environment. Applied and Environmental Microbiology 68: 5625-5633.

Le Guyader F, M Pommepuy \& M Cormier. 1991. Implantation of Escherichia coli in pilot experiment and the influence of competition on the flora. Canadian Journal of Microbiology 37: 116-121.

Melcher RJ, SE Apitz \& BB Hemmingsen. 2002. Impact of irradiation and polycyclic aromatic hydrocarbon spiking on microbial populations in marine sediment for future aging and biodegradability studies. Applied and Environmental Microbiology 68: 2858-2868.

Pucci GN \& OH Pucci. 2003. Biodegradabilidad de componentes de mezclas naturales de hidrocarburo previamente sometidas a landfarming. Revista Argentina de Microbiología 35: 62-68.

Röling W, MG Milner, D Jones, F Fratepietro, RPJ Swannell \& IG Head. 2004. Bacterial community dynamics and hydrocarbon degradation during a field-scale evaluation of bioremediation on a mudflat beach contaminated with buried oil. Applied and Environmental Microbiology 70: 2603-2613.

Ron EZ \& E Rosemberg. 2002. Biosurfactants and oil bioremediation. Current Opinion in Biotechnology 13: 249252.

Rozen Y \& B Shimshon. 2001. Survival of enteric bacteria in seawater. Microbiological Review 25: 513-529.

Ruberto LA, S Vazquez, A Lobaldo \& WP MacCormack. 2005. Psychrotolerant hydrocarbon-degrading Rhodococcus strains isolated from polluted Antarctic soils. Antartic Soils 17: 47-56.

Russell NJ \& DS Nichols. 1999. Polyunsaturated fatty acids in marine bacteria - a dogma rewritten. Microbiology 145: 767-779.

Toren A, S Navon-Venezia, EZ Ron \& E Rosenberg. 2001. Emulsifying activities of purified alasan proteins from Acinetobacter radioresistens KA53. Applied and Environmental Microbiology 67: 1102-1106.

Vieira RHSF, PD Rodrigues, EA Menezes, NSS Evangelista, EMF Reis, LM Barreto \& FA Gonçalves. 2001. Microbial contamination of sand from major beaches in Fortaleza, Ceará state, Brazil. Brazilian Journal of Microbiology 32: 1-4.

Whyte LG, SJ Slagman, F Pietrantonio, L Bourbonniere, SF Koval, JR Lawrence, E Innis \& CW Greer. 1999. Physiological adaptation involved in alkane assimilation at a low temperature by a Rhodococcus sp. Strain Q15. Applied and Environmental Microbiology 65: 2961-2968.

Received 28 October 2011 and accepted 27 June 2012

Associate Editor: Gabriela Muñoz C. 